Running title: A New Locus for Autosomal Recessive Retinitis Pigmentosa

\title{
A New Locus for Autosomal Recessive Retinitis Pigmentosa Maps to 1p13-1p21
}

Amalia Martínez-Mir,* Mònica Bayés,* Lluïsa Vilageliu,* Daniel Grinberg, ${ }^{*}$ Carmen Ayuso,§ Teresa del Río,§ Blanca García-Sandoval,§ Elena Bussaglia,\# Montserrat Baiget,\# Roser Gonzàlez-Duarte, ${ }^{*}$ and Susana Balcells*

* Departament de Genètica, Facultat de Biologia, Universitat de Barcelona, Spain; § Departamento de Genética, Fundación Jiménez Díaz, Madrid, Spain; and \# Unitat de Genètica Molecular, Hospital de la Santa Creu i Sant Pau, Barcelona, Spain.

Corresponding author: Susana Balcells

Dept. de Genètica

Facultat de Biologia

Universitat de Barcelona

Avda. Diagonal, 645

08071. Barcelona. Spain

Telf.: 34/3/402 1501

Fax: 34/3/411 0969 


\begin{abstract}
Autosomal recessive retinitis pigmentosa ( $\operatorname{arRP}$ ) is characterized by considerable allelic and nonallelic heterogeneity. Mutations have been described in the rhodopsin gene (RHO), the genes encoding the $\alpha$ and $\beta$ subunits of rod phosphodiesterase (PDEA and PDEB) and the gene encoding the $\alpha$ subunit of the cGMP-gated channel (CNCG). In addition, linkage studies in single extended pedigrees have defined two new arRP loci, at 1q and 6p. In order to identify the disease gene in a Spanish consanguineous arRP family, a linkage analysis was undertaken. After testing 102 polymorphic markers, a significant positive lod score $\left(Z_{\max }=3.64\right.$ at $\left.\theta=0\right)$ was obtained with marker D1S188 at 1p13-p21, the same region where the Stargardt and fundus flavimaculatus (FFM) loci were previously defined. Exhaustive ophthalmologic examination of the patients clearly distinguished the disease from the Stargardt and FFM phenotypes, and revealed an atypical form of arRP with choroidal atrophy as a distinctive feature.
\end{abstract}


Retinitis pigmentosa is a clinically and genetically heterogeneous group of retinal degenerations characterized by progressive loss of night and peripheral vision and, eventually, severe visual loss (9). As is the case of the autosomal dominant (adRP) and the $\mathrm{X}$-linked (xlRP) forms of the disease, autosomal recessive retinitis pigmentosa (arRP) is characterized by allelic and nonallelic heterogeneity. Mutations cosegregating with the disease have been described in the rhodopsin gene (RHO) $(15,24)$, the genes encoding the $\alpha$ and $\beta$ subunits of rod phosphodiesterase (PDEA and PDEB, respectively) $(3,10,21,28$, 29) and the gene encoding the $\alpha$ subunit of the cGMP-gated channel (CNCG) (6). In addition, genetic linkage studies in single extended pedigrees have identified two new arRP loci, at $1 \mathrm{q}(18,30)$ and $6 \mathrm{p}(14)$.

Among the Spanish population, 39\% of the RP pedigrees show an autosomal recessive pattern of inheritance (arRP) (2). Here we report the case of a Spanish consanguineous arRP family (M-33) with six out of seven sibs affected (Fig.1). Ophthalmologic examination of both parents revealed no manifestation of RP; the father (who died aged 72), showed no symptoms other than glaucoma, whereas the mother (aged 82 ) is totally asymptomatic. This fact, together with the consanguinity (second-cousin marriage), indicate an autosomal recessive pattern of inheritance. Clinical evaluation of the affected members suggested an aggressive form of the disease, with night blindness as the first symptom appearing in the first decade of life (mean age of onset, 8 years), followed by a decrease in visual acuity, starting at 14 years of age. Fundus examination and fluorescein angiographies (Fig.2) of the affected sibs in the fourth decade of life revealed papillary pallor, attenuated vessels, peripheral scattered pigmentation, bone spicule-like pigmentation reaching some areas of the macula and severe atrophy of the retinal pigment epithelium (RPE). At present, the older sibs show a complete scotoma while the youngest (around 45 years of age) still retain central vision and some peripheral islands. Finally, electrophysiological studies revealed abolished rod and mixed responses and a very diminished cone response. Taking into account the clinical and electrophysiological findings and the autosomal recessive pattern of inheritance, we conclude that the family presents an atypical form of RP with the distinctive feature of choriocapillaris atrophy.

In order to identify the disease gene segregating in this family, we performed a linkage analysis. Three sets of markers were analyzed: those defining loci for RP and other eye disorders; those corresponding to the loci of retina-specific genes and a set of anonymous markers from the Weissenbach set.

Primers for the microsatellite markers were from the MapPairs set (Research Genetics, Huntsville, AL, USA) and those for gene-specific polymorphisms were synthesized commercially according to data from GDB (Johns Hopkins University) or from sequence data in the GenBank/EMBL database. DNA was extracted from peripheral blood leukocytes 
of all the members of the family (except the father) using standard methods (22). Genomic DNA was amplified by the polymerase chain reaction (PCR) in a total reaction volume of 25 $\mu l$ containing $300 \mathrm{ng}$ of genomic DNA, 6.6 pmols of each primer, 1 unit of Dynazyme DNA polymerase (Fynzymes Oy, Espoo, Finland) in the recommended buffer and $200 \mu \mathrm{M}$ dNTPs. Reactions were subjected to 35 cycles of $40 \mathrm{~s}$ at $94{ }^{\circ} \mathrm{C}$ and $30 \mathrm{~s}$ at $45-60^{\circ} \mathrm{C}$ (depending on the primer pair), followed by a final extension step of $5 \mathrm{~min}$ at $72^{\circ} \mathrm{C}$, in a thermal cycler (Perkin Elmer Cetus, Norwalk, CT, USA). The amplified products were then separated by electrophoresis on $6 \%$ non-denaturing polyacrylamide gels and stained with ethidium bromide.

Linkage analysis was carried out using the LINKAGE package, version 5.1 (16). Population allele frequencies for those markers that showed evidence of linkage were calculated in a sample of 76 chromosomes.

The eight members of the family were typed for 102 polymorphic markers. Significant exclusion was obtained for all loci and gene markers except for those corresponding to Stargardt's disease and late onset fundus flavimaculatus (FFM), at 1p13-p21 (7, 12). Haplotypes for the most informative markers in this region are shown in Figure 1. Recombination events in individuals II.3 and II.7 locate the disease locus within a $10.3 \mathrm{cM}$ interval between markers D1S167 and D1S497. This interval includes a homozygosity region of at least $3.5 \mathrm{cM}$ (D1S435 through D1S236). Two-point lod scores between the disease and the markers are summarized in Table 1. Maximum lod scores were obtained at $\theta=0.0$ for all markers from D1S435 to D1S236. However, the highest value corresponded to $\operatorname{D1S188}\left(Z_{\max }=3.64\right)$, since a low-frequency allele segregates in the family.

A candidate gene, GNAT2 ( $\alpha$ subunit of cone transducin), is physically located at 1p13 $(4,20)$. However, Gerber et al. (8) showed that this gene is not responsible for Stargardt's disease. To test the possible involvement of GNAT2 in arRP in family M-33, we analyzed an A-to-G transition in exon five of the gene (25). Lack of cosegregation between this polymorphism and the disease ruled out GNAT2 as a cause of arRP in the family. Recently, Anderson et al. (1) constructed a YAC contig of the region encompassing the Stargardt locus but failed to place either GNAT2 or another candidate, the retinal pigment epitheliumspecific protein gene (RPE65), to any YAC in this region.

The linkage data presented here identify a locus for an atypical form of arRP, with choroidal atrophy as a distinctive feature, at 1p13-p21. This is the same region where the Stargardt and FFM loci have been defined. A comparison of the minimal criteria for diagnosis of Stargardt's disease (12) with the clinical findings in family M-33 is shown in Table 2. Although the early age of onset of the disease in M-33 is similar to that of Stargardt, the ERG patterns are quite distinct, particularly the abolished rod response. Additionally, fundus findings in M-33 show features of RP that are clearly different from Stargardt's. The above arguments can also be applied to rule out FFM in the family, since its clinical findings 
are basically the same as those for Stargardt except for a delayed age of onset and a slower progression of the disease (7).

The fact that three retinal degenerations map to the same genomic region is reminiscent of the situation at region 11q13, where loci for several distinct eye disorders have been mapped $(13,17,19,26,27)$. An interesting question is whether these three traits are caused by mutations in the same gene. Allelic heterogeneity has been documented. For instance, mutations at the peripherin/RDS gene have been associated with adRP, retinitis pigmentosa punctata albescens and several types of macular dystrophies $(11,23,30,31)$. Moreover, mutations at the PDEB and RHO genes may lead either to RP or to congenital stationary night blindness. The alternative to allelic heterogeneity would be a situation in which different genes, clustered together in region 1p13-p21, were responsible for these three clinically distinct entities. The identification of the causative genes may clarify this issue. 


\section{Acknowledgments}

The authors are grateful to Dr. Alan C. Bird for his invaluable comments on the ophthalmologic data.

They whish to thank the members of family U.G. for their generous cooperation and to acknowledge Robin Rycroft for revising the English.

This work was supported by Spanish CICYT (SAF93-0479-062-01; SAF96-0329) and the "Federación de Asociaciones de Afectados de Retinosis Pigmentaria del Estado Español" (FAARPE). A. Martínez-Mir and M. Bayés are recipients of a fellowship from the "Generalitat de Catalunya". 


\section{References}

1. Anderson, K. L., Baird, L., Lewis, R. A., Chinault, A. C., Otterud, B., Leppert, M., and Lupski, J. R. (1995). A YAC contig encompassing the recessive Stargardt disease gene (STGD) on chromosome 1p. Am. J. Hum. Genet. 57: 1351-1363.

2. Ayuso, C., García-Sandoval, B., Najera, C., Valverde, D., Carballo, M., and Antiñolo, G. (1995). Retinitis pigmentosa in Spain. Clin. Genet. 48: 120-122.

3. Bayés, M., Giordano, M., Balcells, S., Grinberg, D., Vilageliu, L., Martínez, I., Ayuso, C., Benítez, J., Ramos-Arroyo, M. A., Chivelet, P., Solans, T., Valverde, D., Amselem, S., Goossens, M., Baiget, M., Gonzàlez-Duarte, R., and Besmond, C. (1995). Homozygous tandem duplication within the gene encoding the beta-subunit of rod phosphodiesterase as a cause for autosomal recessive retinitis pigmentosa. Hum. Mutat. 5: 228-234.

4. Blatt, C., Eversole-Cire, P., Cohn, V. H., Zollman, S., Fournier, R. E. K., Mohandas, L. T., Nesbitt, M., Lugo, T., Jones, D. T., Reed, R. R., Weiner, L. P., Sparkes, R. S., and Simon, M. I. (1988). Chromosomal localization of genes encoding guanine nucleotide-binding protein subunits in mouse and human. Proc. Natl. Acad. Sci. USA 85: 7642-7646.

5. Buetow, K. H., Weber, J. L., Ludwigsen, S., Scherpbier-Heddema, T., Duyk, G. M., Sheffield, V. C., Wang, Z., and Murray, J. C. (1994). Integrated human genome-wide maps constructed using the CEPH reference panel. Nature Genet. 6: 391-393.

6. Dryja, T. P., Finn, J. T., Peng, Y. W., Mcgee, T. L., Berson, E. L., and Yau, K. W. (1995). Mutations in the gene encoding the alpha subunit of the rod cGMP-gated channel in autosomal recessive retinitis pigmentosa. Proc. Natl. Acad. Sci. USA 92: 10177-10181.

7. Gerber, S., Rozet, J. M., Bonneau, D., Souied, E., Camuzat, A., Dufier, J. L., Amalric, P., Weissenbach, J., Munnich, A. , and Kaplan, J. (1995). A gene for late-onset fundus flavimaculatus with macular dystrophy maps to chromosome 1p13. Am. J. Hum. Genet. 56: 396-399.

8. Gerber, S., Rozet, J. M., Bonneau, D., Souied, E., Weissenbach, J., Frezal, J., Munnich, A., and Kaplan, J. (1995). Exclusion of the cone-specific alpha-subunit of the transducin gene in Stargardt's disease. Hum. Genet. 95: 382-384. 
9. Heckenlively, J. R., Yoser, S. L., Friedman, L. H., and Oversier, J. J. (1988). Clinical findings and common symptoms in retinitis pigmentosa. Am. J. Ophtalmol. 105: 504-511.

10. Huang, S. H., Pittler, S. J., Huang, X. H., Oliveira, L., Berson, E. L., and Dryja, T. P. (1995). Autosomal recessive retinitis pigmentosa caused by mutations in the alpha subunit of rod cGMP phosphodiesterase. Nature Genet. 11: 468-471.

11. Kajiwara, K., Sandberg, M. A., Berson, E. L., and Dryja, T. P. (1993). A null mutation in the human peripherin/RDS gene in a family with autosomal dominant retinitis punctata albescens. Nature Genet. 3: 208-212.

12. Kaplan, J., Gerber, S., Larget-Piet, D., Rozet, J. M., Dollfus, H., Dufier, J. L., Odent, S., Postel-Vinay, A., Janin, N., Briard, M. L., Frezal, J., and Munnich, A. (1993). A gene for Stargardt's disease (fundus flavimaculatus) maps to short arm of chromosome 1. Nature Genet. 5: 308-311.

13. Kimberling, W. J., Moller, C. G., Davenport, S., Priluck, I. A., Beighton, P. H., Greenberg, J., Reardon, W., Weston, M. D., Kenyon, J. B., Grunkemeyer, J. A., Dahl, S. P., Overbeck, L. D., Blackwood, D. J., Brower, A. M., Hoover, D. M., Rowland, P., and Smith, R. J. H. (1992). Linkage of Usher syndrome type-I tene (USH1B) to the long arm of chromosome-11. Genomics 14: 988-994.

14. Knowles, J. A., Shugart, Y., Banerjee, P., Gilliam, T. C., Lewis, C. A., Jacobson, S. G., and Ott, J. (1994). Identification of a locus, distinct from RDS-peripherin, for autosomal recessive retinitis pigmentosa on chromosome 6p. Hum. Mol. Genet. 3: 1401-1403.

15. Kumaramanickavel, G., Maw, M., Denton, M. J., John, S., Srikumari, C. R. S., Orth, U., Oehlmann, R., and Gal, A. (1994). Missense rhodopsin mutation in a family with recessive RP. Nature Genet. 8: 10-11.

16. Lathrop, G. M., and Lalouel, J. M. (1984). Easy calculations of Lod scores and genetic risks on small computers. Am. J. Hum. Genet. 36: 460-465.

17. Leppert, M., Baird, L., Anderson, K. L., Otterud, B., Lupski, J. R., and Lewis, R. A. (1994). Bardet-Biedl syndrome is linked to DNA markers on chromosome 11q and is genetically heterogeneous. Nature Genet. 7: 108-112. 
18. Leutelt, J., Oehlmann, R., Younus, F., Vandenborn, L. I., Weber, J. L., Denton, M. J., Mehdi, S. Q., and Gal, A. (1995). Autosomal recessive retinitis pigmentosa locus maps on chromosome 1q in a large consanguineous family from Pakistan. Clin. Genet. 47: 122-124.

19. Li, Y., Müller, B., Fuhram, C., Erik van Nouhuys, C., Laqua, H., Humphries, P., Schwinger, E., and Gal, A. (1992). The autosomal dominant familial exudative vitreretinopathy locus maps on $11 \mathrm{q}$ and is closely linked to D11S533. Am. J. Hum. Genet. 51: 749-754.

20. Magovcevic, I., Weremowicz, S., Morton, C. C., Fong, S. L., Berson, E. L., and Dryja, T. P. (1995). Mapping of the human cone transducin alpha-subunit (GNAT2) gene to $1 \mathrm{p} 13$ and negative mutation analysis in patients with Stargardt disease. Genomics 25: 288290.

21. McLaughlin, M. E., Ehrhart, T. L., Berson, E. L., and Dryja, T. P. (1995). Mutation spectrum of the gene encoding the beta subunit of rod phosphodiesterase among patients with autosomal recessive retinitis pigmentosa. Proc. Natl .Acad. Sci. USA 92: 3249-3253.

22. Miller, S. A., Dyke, D. D., and Polesky, H. F. (1988). A simple salting out procedure for extracting DNA from human nucleated cells. Nucleic Acids Res. 16: 1215.

23. Nichols, B. E., Sheffield, V. C., Vandenburgh, K., Drack, A. V., Kimura, A. E., and Stone, E. M. (1993). Butterfly-shaped pigment dystrophy of the fovea caused by a point mutation in codon 167 of the RDS gene. Nature Genet. 3: 202-207.

24. Rosenfeld, P. J., Cowley, G. S., McGee, T. L., Sandberg, M. A., Berson, E. L., and Dryja, T. P. (1992). A null mutation in the rhodopsin gene causes rod photoreceptor dysfunction and autosomal recessive retinitis pigmentosa. Nature Genet. 1: 209-213.

25. Rozet, J., Gerber, S., Bonneau, D., Munnich, A., and Kaplan, J. (1994). DsaI polymorphism at the human cone transducin $\alpha$-subunit (GNAT2) detected by PCR. Hum. Mol. Genet. 3: 1030.

26. Stone, E. M., Kimura, A. E., Folk, J. C., Bennett, S. R., Nichols, B. E., Streb, L. M., and Sheffield, V. C. (1992). Genetic linkage of autosomal dominant neovascular inflamatory vitreoretinopathy to chromosome 11q13. Hum. Mol. Genet. 1: 685-689. 
27. Stone, E. M., Nichols, B. E., Streb, L. M., Kimura, A. E., and Sheffield, V. C. (1992). Genetic linkage of vitelliform macular degeneration (Best's disease) to chromosome 11q13. Nature Genet. 1: 246-250.

28. Valverde, D., Baiget, M., Seminago, R., del Rio, E., García-Sandoval, B., del Rio, T., Bayés, M., Balcells, S., Martínez, A., Grinberg, D., and Ayuso, C. (1996). Identification of a novel ARG552GLN in exon 13 of the $\beta$-subunit of rod phosphodiesterase gene in a Spanish family with autosomal recessive retinitis pigmentosa. Hum. Mutat., in press.

29. Valverde, D., Solans, T., Grinberg, D., Balcells, S., Vilageliu, L., Bayes, M., Chivelet, P., Besmond, C., Goossens, M., Gonàlez Duarte, R., and Baiget, M. (1996). A novel mutation in exon 17 of the beta-subunit of rod phosphodiesterase in two RP sisters of a consanguineous family. Hum. Genet. 97: 35-38.

29. Van Soest, S., Vandenborn, L. I., Gal, A., Farrar, G. J., Bleekerwagemakers, L. M., Westerveld, A., Humphries, P., Sandkuijl, L. A., and Bergen, A. A. B. (1994). Assignment of a gene for autosomal recessive retinitis pigmentosa (RP12) to chromosome 1q31-q32.1 in an inbred and genetically heterogeneous disease population. Genomics 22: 499-504.

30. Weleber, R. G., Carr, R. E., Murphey, W. H., Sheffield, V. C., and Stone, E. M. (1993). Phenotypic variation including retinitis-pigmentosa, pattern dystrophy, and fundus flavimaculatus in a single family with a deletion of codon 153 or 154 of the peripherin/RDS gene. Arch. Ophthalmol. 111: 1531-1542.

31. Wells, J., Wroblewski, J., Keen, J., Inglehearn, C., Jubb, C., Eckstein, A., Jay, M., Arden, G., Bhattacharya, S., Fitzke, F., and Bird, A. (1993). Mutations in the human retinal degeneration slow (RDS) gene can cause either retinitis pigmentosa or macular dystrophy. Nature Genet. 3: 213-218. 
FIG. 1. Pedigree of family M-33. Black symbols represent affected individuals. Haplotypes for the most informative markers from the $1 \mathrm{p}$ region are shown. The haplotype most likely segregating with the disease is boxed.

FIG. 2. Characteristic clinical features of family M-33. (a) Fundus photograph of the left eye of individual II.1; note the choriocapillaris atrophy allowing visualization of the large choroidal vessels; (b) Fluorescein angiography of individual II.6 showing the severe choriocapillaris atrophy. 
TABLE 1

Two-point lod scores between ARRP and Markers on Chromosome 1p13-p21

\begin{tabular}{|c|c|c|c|c|c|c|c|c|c|}
\hline \multirow[b]{2}{*}{ Marker } & \multicolumn{9}{|c|}{ Lod score $(Z)$ at recombination fraction $(\theta)$} \\
\hline & 0 & 0.01 & 0.05 & 0.10 & 0.20 & 0.30 & 0.40 & $\theta_{\max }$ & $Z_{\max }$ \\
\hline D1S167 & $-\infty$ & 0.688 & 1.132 & 1.122 & 0.838 & 0.492 & 0.176 & 0.07 & 1.153 \\
\hline D1S435 & 2.673 & 2.606 & 2.340 & 2.015 & 1.401 & 0.837 & 0.320 & 0.00 & 2.673 \\
\hline D1S188 & 3.648 & 3.569 & 3.251 & 2.848 & 2.036 & 1.247 & 0.522 & 0.00 & 3.648 \\
\hline D1S2849 & 2.639 & 2.573 & 2.311 & 1.991 & 1.386 & 0.829 & 0.318 & 0.00 & 2.639 \\
\hline D1S2868 & 2.567 & 2.502 & 2.247 & 1.936 & 1.349 & 0.809 & 0.309 & 0.00 & 2.567 \\
\hline D1S424 & 2.714 & 2.646 & 2.377 & 2.047 & 1.422 & 0.848 & 0.324 & 0.00 & 2.714 \\
\hline D1S236 & 2.639 & 2.573 & 2.311 & 1.991 & 1.386 & 0.829 & 0.318 & 0.00 & 2.639 \\
\hline D1S497 & $-\infty$ & 1.648 & 2.059 & 1.995 & 1.557 & 0.980 & 0.369 & 0.06 & 2.065 \\
\hline
\end{tabular}




\section{TABLE 2}

\section{Comparison between the minimal criteria for diagnosis of Stargardt's disease and the clinical findings in family M33}

\begin{tabular}{|c|c|c|}
\hline Phenotypic trait & Stargardt's disease & M33 phenotype \\
\hline Loss of visual acuity & $7-12$ years of age & 14 years of age \\
\hline Alteration of the macula & prevalent & some bone-spicule spots \\
\hline Aspect of peripheral retina & normal & pigmented \\
\hline Calibre of retinal vessels & normal & attenuated \\
\hline Pigmented bone-spicules & absent & present \\
\hline Fluorescein angiography & abnormal choroid & diffuse choriocapillaris atrophy \\
\hline Visual field & central scotoma & $\begin{array}{l}\text { total scotoma (older sibs), retention of } \\
\text { central visual field (younger sibs) }\end{array}$ \\
\hline Color vision & abnormal & n.a. ${ }^{a}$ \\
\hline ERG & $\begin{array}{l}\text { normal in early stage and abnormal } \\
\text { photopic ERG in advanced stage }\end{array}$ & $\begin{array}{l}\text { abolished scotopic and mixed ERG, } \\
\text { decreased photopic ERG }\end{array}$ \\
\hline
\end{tabular}

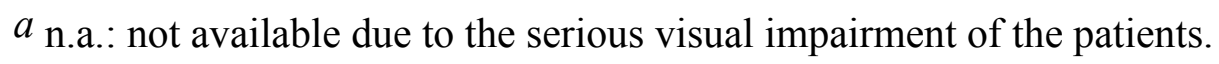



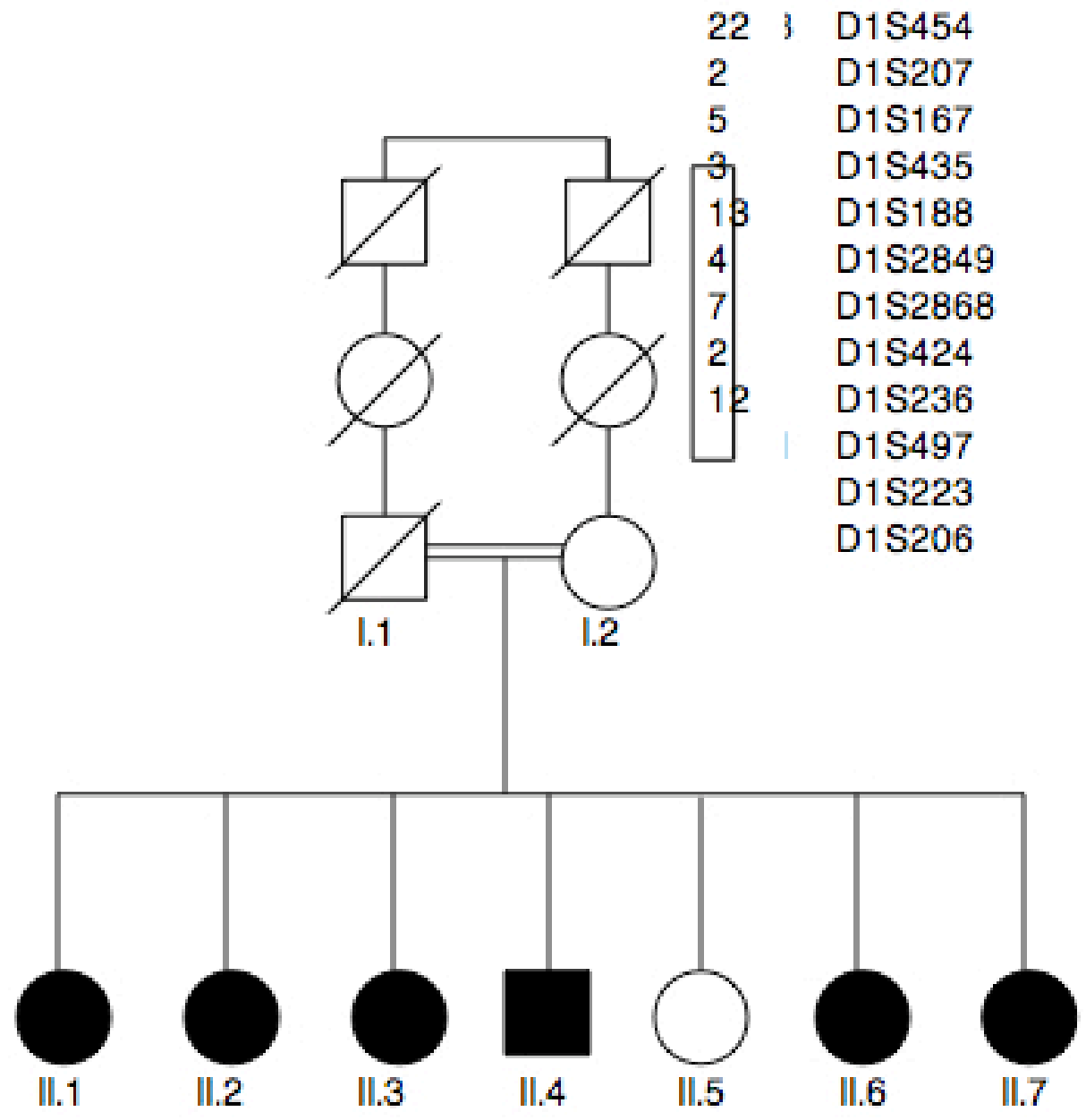

$\begin{array}{llllllll}\text { D1S454 } & 2122 & 2122 & 2113 & 2122 & 2113 & 2122 & 2122\end{array}$

$\begin{array}{llllllll}\text { D1S207 } & 22 & 22 & 21 & 22 & 21 & 22 & 22\end{array}$

D1S167 $553 \quad 55 \quad 53 \quad 55 \quad 57 \quad 55 \quad 55$

D1S435

D1S188

D1S2849

D1S2868

$\begin{array}{llll}313 & 33 & 133 & 33 \\ 134 & 1313 & 4713 & 1313 \\ 477 & 4747 & 247 & 4747 \\ 22 & 22 & 122 & 22 \\ 1212 & 1212 & 12 & 1212 \\ & & & \end{array}$

34

D1S424

D1S236

D1S497

D1S223

$1322 \quad 1313 \quad 133$

\begin{tabular}{l|ll}
4773 & 4747 & 4747
\end{tabular}

$21 \quad 22 \quad 32$

$1331 \quad 1212 \quad 2211$

D1S206 


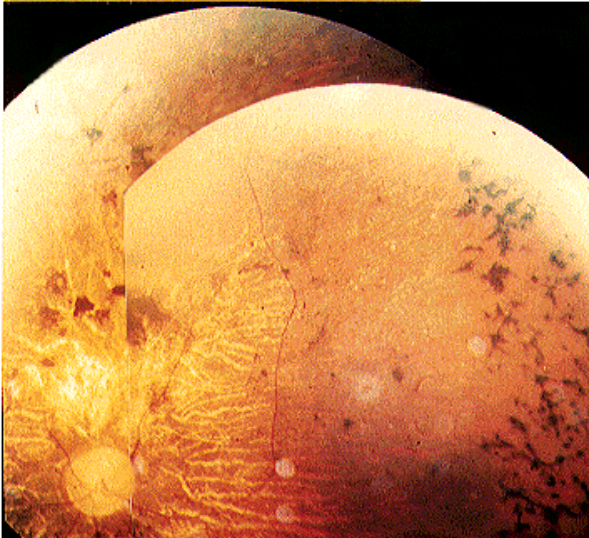




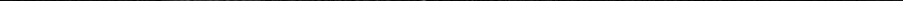

